\title{
Microplastics-How and What Do University Students Know about the Emerging Environmental Sustainability Issue?
}

\author{
Svatava Janoušková ${ }^{1,2, *}$, Pavel Teplý ${ }^{1}$ (D) David Fatka ${ }^{1}$, Milada Teplá $^{1}{ }^{\circledR}$, Tomáš Cajthaml $^{3}$ \\ and Tomáš Hák ${ }^{2,4}$ (D) \\ 1 Department of Teaching and Didactics of Chemistry, Faculty of Science, Charles University, \\ 12802 Prague, Czech Republic; pavel.teply@natur.cuni.cz (P.T.); david.fatka@natur.cuni.cz (D.F.); \\ milada.tepla@natur.cuni.cz (M.T.) \\ 2 Environment Centre, Charles University, 16200 Prague, Czech Republic; tomas.hak@czp.cuni.cz \\ 3 Institute for Environmental Studies, Faculty of Science, Charles University, 12801 Prague, Czech Republic; \\ tomas.cajthaml@natur.cuni.cz \\ 4 Faculty of Humanities, Charles University, 18200 Prague, Czech Republic \\ * Correspondence: svatava.janouskova@natur.cuni.cz
}

Received: 30 September 2020; Accepted: 3 November 2020; Published: 5 November 2020

check for updates

\begin{abstract}
For a successful transition towards sustainability, people need information and knowledge to understand the complex interconnectedness of social, natural, and social-natural systems. In order for people to be able to take a position on a number of environmental and social issues, and make decisions arising from these challenges, they need to use environmental literacy. We have come up with a tool to answer the question of how students access information about new environmental topics in the media, and how they transform it into environmental knowledge. Almost 400 students from seven Czech universities took part in a combined knowledge test and context questionnaire on microplastics (information based on the previous analysis of selected major web media). More than a third of students tested identified mass media as their main source of knowledge. Most students, however, already had some simple partial knowledge about the topic-the level of commonly discussed information that students remember and then just reproduce. Our statistically evaluated results may help teachers improve the quality of their instruction, curriculum, and subsequently students' achievement and environmental civic competencies. The results present original findings complementing international research on the role of education and mass media in environmental sustainability knowledge.
\end{abstract}

Keywords: environmental literacy; microplastics; knowledge of microplastics; mass media; environmental sustainability

\section{Introduction}

Human society faces a broad scale of more or less complex sustainability challenges. People are obliged to take a position on a number of environmental as well as social issues and make decisions to cope with the problems arising from these challenges [1,2]. Environmental sustainability must take into consideration in mostly quantifiable terms the multiplicity of functions associated with the environment [3], while the concept of social development is ambiguous and defined by many characteristics observed in various areas of life, such as education, health, or societal affluence [4]. However, not all these topics can be included in formal school curricula since new challenges keep constantly appearing. For that reason, society requires people who are literate and use different types 
of literacies, including environmental literacy, for critical evaluation of a position or a knowledge claim, and to find out the extent to which there are reasons for their acceptance [1].

For several decades, studies have strived to define a concept of environmental literacy, and a number of papers on this topic are still being published (e.g., [1,5-7]). A vast number of studies are concerned with approaches and methods for developing environmental literacy in education (e.g., [2,8,9]. There are also some studies measuring the general ecological/environmental knowledge of different target groups in the population [10-13], as well as their attitudes (e.g., [14,15]). However, little is known about people's awareness of new environmental issues, although in many cases it is just new environmental issues that people have to assess and take a position on. In other words, it is people's knowledge concerning new environmental topics which they obtain information about through informal education that can show their real environmental literacy, as it is understood, for example, by Yacoubian or Coyle [1,6].

In the Czech Republic, as in many other European countries, environmental education is a compulsory part of education. This means that environmental literacy has been developed extensively for most students and the level of environmental literacy of students entering higher education may be assumed to be quite high. However, in both formal and informal meetings with colleagues from other universities, we have learnt that environmental literacy, especially in terms of students' endeavours to gather information about new environmental themes, and critical evaluation of new environmental information, is not at the desired level.

In our article, we have come up with a tool-a test about a new environmental issue (microplastics) - that answers the question "Have students got information about the new environmental topics discussed in the media?" and "How do students transform the environmental information they receive via informal education into environmental knowledge?" In other words, what is their real environmental knowledge? The article describes our approach to the testing issue selection, tool construction, and proving of its content and construct validity. Further in the text, we have brought results from the first pilot survey of environmental literacy in six universities in the Czech Republic. The data we present may serve the university teachers to be able to adapt their courses to deepen students' environmental literacy. Based on the semi-structured interviews with the teachers whose students took part in the survey, we found out the teachers used the results for that purpose.

\section{Environmental Knowledge-A Prerequisite of Environmental Literacy}

Like other complex concepts, environmental literacy has not yet been fully theoretically anchored, although there have been many attempts to define the concept properly over the last three decades. According to [5], environmental literacy is " ... the capacity to perceive, appropriately interpret the health of the environmental systems and take appropriate action to maintain, restore, or improve the health of those systems." Wolfe defines it as "... a basic understanding of the concepts and knowledge of the issues and information relevant to the health and sustainability of the environment as well as environmental issues related to human health" [16] (p. 302). Scholz and Binder use another (top-down) approach to the definition: " ... the capability of an assembly of subunits of a society to jointly generate appropriate knowledge, proper strategies, and reasonable adaptations to changing environmental conditions and adequately anticipate unwanted effects of human actions on the environment" [17] (p. 13). Coyle distinguishes three levels of environmental literacy: (i) simple awareness-knowing that the topic exists and is important but the person is unfamiliar with its complexities; (ii) personal conduct knowledge- understanding of a class of environmental subjects simply and easily grasped that lend themselves to changes in personal conduct but that do not require detailed comprehension; and (iii) (real) environmental literacy-the person has deep knowledge and skills and uses them in the actual field application [6]. All definitions explicitly or implicitly mention knowledge as one of the necessary prerequisites of environmental literacy. The crucial role of knowledge for environmental literacy is supported also by McBride et al. who analysed about fifteen various frameworks of environmental 
literacy developed and applied within the field of environmental education. Knowledge is mentioned in all of them [18].

Knowledge is thus a fundamental component of environmental literacy; however, it is crucial to be based on up-to-date findings and information and on practical measures taken by society to handle the relevant problems as well. But what is, in fact, meant by "knowledge?" Sometimes people believe they know more about certain environmental issues than they really do and thus they consider their knowledge claims and positions toward new issues rational and correct. Coyle states that about $80 \%$ of Americans are influenced by incorrect and/or outdated environmental facts. For example, in 2005 about 120 million Americans thought that spray cans still contained chlorofluorocarbons (CFCs), even though this use of halogenated hydrocarbons was banned in the US in 1978 [6]. Rosling further calls attention to the outdated yet still persisting belief about endangered species: Three particular species were listed as critically endangered in 1996; since then, over a long period, their populations have recovered and increased. Nevertheless, the lay public mostly assesses them as still severely endangered [19].

The above examples refer to outdated, obsolete knowledge. We may, however, often also witness people with incorrect knowledge ("misconceptions"/alternative conceptions). The term misconception refers to people's ideas which are incompatible with currently accepted scientific knowledge [20-22] and may finally result in incorrect (inefficient or even harmful) responses to the existing problems.

Another important phenomenon is "preconception" which may also influence attitudes to environmental issues and induced risks. Preconception is defined as being an idea that exists before sufficient information becomes available to be able to form comprehensive and correct knowledge-some authors also refer to it as pre-existing concepts (e.g., [23,24]). Preconception follows on from previous patterns or concepts that have been formed during our lifetimes, and it is influenced by the community we live in, stereotypes, mass media, and others. Nevertheless, this idea about the natural world need not be consistent with generally accepted scientific facts or can be incomplete as demonstrated by [25]. Preconceptions may easily become misconceptions, but there is evidence that this is not necessarily so [20].

In accordance with the above statements we see personal (environmental) knowledge as an individual knowledge in terms of idiosyncratic science; it is an idea believed or being entertained as being plausible by a person regardless of its objective correctness [22]; we can also call it subjective knowledge [26]. Obviously, environmental literacy frameworks do not consider any personal ideas desirable (right) knowledge, but rather consider this knowledge as currently valid scientific concepts mastered by people. However, each scientific concept can be of varied complexity, so obtaining the right—complex-knowledge often requires the involvement of other higher cognitive skills such as analysis, synthesis, or evaluation referred to above as the instrumental-knowledge. These higher cognitive skills are also part of most environmental literacy frameworks [18]. Use of the instrumental knowledge is then crucial when information comes from informal sources-for example from media or community sharing and people have to process it (analyse, synthetize, and evaluate).

In our article we have seen (environmental) knowledge-a prerequisite of environmental literacy-as a well-understood scientific concept that corresponds with the current understanding of environmental facts (objects, phenomena, and processes). Acquisition of such complex knowledge usually requires an acquiring system of partial knowledge using a system of different cognitive skills as described by the Bloom theory [27].

From our point of view, knowledge is a cornerstone of environmental literacy, since it enables people to assess political claims, make decisions, and take action. Other experts also recognize knowledge and understanding environmental issues as a key component of the environmental literacy, viewed and defined from the perspective of environmental competencies [7]. At the same time, we acknowledge that there are other important aspects of environmental literacy like responsibility towards the environment, motivation towards the environment, morals, and ethics regarding environmental issues, social engagement related to the environment, and intention to act to protect the environment; in other 
words, people's behaviour is not affected only by knowledge but also significantly by environmental emotions [7,28-30].

\section{Source of Knowledge}

Education undoubtedly plays an important role in information gathering and knowledge building. There is general wisdom that environmental education has a significant influence on environmental knowledge, awareness, and attitudes [31,32].

The forms of education available to people change during their lifetimes. Formal education (in-school learning) based on proven and reliable information sources (textbooks, trained, and knowledgeable teachers), with the possibility of corrections of information acquired outside of school and alternative conceptions or preconceptions, decreases during one's lifetime, while the other two types (non-formal and informal education) increase, and finally dominate. Non-formal education is usually structured, planned but highly adaptable, in various institutions, and directly or indirectly teacher/expert-led. Informal education/learning refers to situations in life that come about naturally - what a person is reading, viewing, and listening to. Such situations are spontaneous, unstructured, and mostly learner-led [33]. We consider as most important who the information provider or conveyer is, regardless of the type of education: an expert (e.g., a trained and knowledgeable teacher) or non-expert (an untrained and experienced person in the field, who may be an intelligent and educated person but without expertise in the field-a lay person). Expert views usually guarantee correct and/or truthful information delivered in both written and oral forms. Thus, people usually receive correct information in the process of formal education and some forms of non-formal education, as well as from specialized texts (scientific books and journals). Formal, compulsory, environmental education, however, ends at the level of higher secondary education and further on only in various programmes - typically based on more intrinsic motivation - and public media, and recently social media, become a key source of information (knowledge) for environmental literacy.

How do data and statistics support these findings? In the EU, the adults engaging in formal education and training comprise a fairly small share of the population (with the exception of young adults)—about $17 \%$. The informal learning settings such as community resource centres or libraries. are used by about $32 \%$ of Europeans. The majority of people think they can learn best in very informal settings, especially through home activities [34]. TV news is the main source of information about the environment: $42 \%$ of Europeans get information from the internet and social media; only $8 \%$ get information from books or scientific publications. Without a doubt, media is an important agenda setter for environmental issues strongly influencing public views. People consider media a key source of information. Despite the fact that only $51 \%$ of Europeans trust TV as the main source of information, even fewer people trust the internet (only 34\%) and only two out of ten Europeans (20\%) tend to trust online social networks [35]. The importance of media in students' learning is also discussed by [36].

Young people, despite still being in the formal education system, may miss out on a great deal of environmental education since it is not a compulsory component. Therefore, it is extremely interesting and perhaps important for university teachers as well, to find out where they get information on the topical environmental issue-microplastics. Evaluation of the correctness of the information they possess and the attitudes towards the microplastics impacts they hold, is also of great importance since it might contribute to a discussion on their level of environmental knowledge and on whether environmental education should be maintained as an integral part of university curricula [37-39].

\section{Survey Design and Methods}

\subsection{Assessment Tool Development}

To answer the question "How do students transform the environmental information they receive through informal education into environmental knowledge?" we have developed an assessment tool combining a knowledge test and a context questionnaire. Since the tool should serve as a quick analytic 
aid for teachers, we were limited by its length. Teachers were mostly willing to spend no more than 20 min on the testing.

The first step was identification of the new environmental theme widely discussed in online media (online newspapers and TV news) for about a year prior to the survey (January-November 2018) being conducted. The online media was chosen since young people mostly use various digital platforms including online newspapers [40]. Four authors of this text (with different fields of interest and disciplines) conducted their own search of widely used online public media (15 of the most visited media). Each author put together a list of environmental themes discussed in their pre-selected and agreed set of media and rough information about how the themes are communicated in terms of complexity and accuracy of its scientific concept. After a deep discussion, the theme "Microplastics" was chosen. There were four reasons for its selection: (i) The theme is not a part of elementary, high school, or university curricula, (ii) the theme was widely covered in the analysed media, (iii) it varied in complexity of the published information so it enabled them to develop the testing questions to verify particular knowledge about microplastics at different difficulty levels, and (iv) the theme was often presented from a one-sided view, or an emotional content was present, so some preconceptions or alternative concepts might be developed by readers.

An in-depth analysis of 38 online newspaper articles and text broadcasts was made. The media expert was asked about how many newspapers and broadcasts dealing with microplastics were presented in the most used online-media (the first 15 of the most visited). According to the Netmonitor data, the term "microplastics" appeared in 105 reports; however, not all of them dealt exclusively with that theme. We have analysed 36\% of all published reports on microplastics. It is worth mentioning that the core information obtained from the main news agencies is repeated with slight variations in different media. We sought to select as many different (unique) microplastics-related topics as possible for the analysis to see how the topic of microplastics is communicated.

Based on the facts presented in the analysed media and the way they are presented, we formulated five open-ended questions of various levels of difficulty. The difficulty is understood here as cognitive performances that people have to complete in order to acquire environmental partial knowledge, on which the comprehensive understanding of the theme is built. The difficulty scale was derived from the revised Bloom's taxonomy [41]. Simple partial knowledge means just remembering, recalling, and repeating what has been presented in the media or through any other informal way in society (Factual Knowledge in the Knowledge Dimension and Remember in the Cognitive Process Dimension in Revised Bloom's taxonomy). Derived partial knowledge requires just making sense of what the students have already learnt (Factual Knowledge in the Knowledge Dimension and Understand, in the Cognitive Process Dimension in Revised Bloom's taxonomy). Extended partial knowledge requires the understanding of or application of knowledge to obtain more specific knowledge than we can gain from primary information sources like public media or public debate (Knowledge Dimension-Factual Knowledge; Cognitive Process Dimension-Apply in Revised Bloom's taxonomy). To determine this cognitive level, we used the Colvin-Keene Model of Students' Information Literacy Activities linked to the Bloom's Taxonomy [42]. Complex partial knowledge is the knowledge which it is necessary to have to involve higher cognitive skills such as analysis, synthesis, or evaluation (analysing or evaluating in Bloom's taxonomy). This knowledge can be built on other partial knowledge; however, its adoption does not mean that people understand the whole theme. The difficulty of partial knowledge was determined by the authors of the article and examined by a group of four independent education experts. Table 1 provides information on the questions, correct answers, and difficulties according to Bloom's taxonomy. The fourth column describes preconceptions/alternative concepts that might be developed due to a one-sided-view presentation of the theme in media or emotional discourse of the text. The content validity of the instrument was ensured by engaging a subject matter expert panel [43] comprised of five scientists with at least a doctoral degree. 
Table 1. A knowledge test on microplastics: questions, correct answers, and its difficulties, and potential preconceptions.

\begin{tabular}{|c|c|c|c|}
\hline Question & Correct Answer & $\begin{array}{l}\text { Partial Knowledge Difficulty } \\
\text { and Explanation }\end{array}$ & $\begin{array}{l}\text { Preconceptions or } \\
\text { Alternative Concept } \\
\text { Source (If Any) }\end{array}$ \\
\hline $\begin{array}{l}\text { 1. What are the sources } \\
\text { of microplastics? }\end{array}$ & $\begin{array}{l}\text { Primary sources-personal care } \\
\text { products-cosmetics, plastic } \\
\text { pellets, or plastic fibres used in } \\
\text { industrial manufacturing and/or } \\
\text { larger plastics products. } \\
\text { Secondary sources—all the } \\
\text { examples of "pieces or particles" } \\
\text { products clearly made from } \\
\text { plastics were counted as good } \\
\text { answers (e.g., pieces of plastic } \\
\text { bags; particles created by } \\
\text { laundering of synthetic cloth). } \\
\text { Just one source named was } \\
\text { sufficient to be given credit. }\end{array}$ & $\begin{array}{l}\text { Simple partial knowledge } \\
\text { Media provides all the necessary } \\
\text { information about the microplastics } \\
\text { sources-in this way. Moreover, you can } \\
\text { obtain information through a } \\
\text { spontaneous everyday process } \\
\text { (conversation, public debate, TV). }\end{array}$ & None \\
\hline $\begin{array}{l}\text { 3. Where in the } \\
\text { environment could you find } \\
\text { microplastics? Please, } \\
\text { indicate all the components of } \\
\text { the environment where the } \\
\text { microplastics can occur. }\end{array}$ & $\begin{array}{l}\text { All main environmental } \\
\text { components-water, soil, } \\
\text { atmosphere, biota. } \\
\text { All the components of the } \\
\text { environment had to be named to } \\
\text { be given credit for the } \\
\text { right answer. }\end{array}$ & $\begin{array}{l}\text { Complex partial knowledge } \\
\text { Naming all the environment media } \\
\text { requires higher cognitive } \\
\text { skills-reasoning about the sources and } \\
\text { size of microplastics to answer correctly. } \\
\text { The media mostly provides a one-sided } \\
\text { view-the occurrence of microplastics } \\
\text { in fresh water, sea water, and water } \\
\text { biota. It does not provide information } \\
\text { about other components of the } \\
\text { environment where microplastics can } \\
\text { be found. Students must apply higher } \\
\text { cognitive skills and conclude that } \\
\text { microplastics are likely to appear in all } \\
\text { components of the environment. It is } \\
\text { not about extended knowledge, because } \\
\text { the research papers mostly deal with } \\
\text { greater details of the problem of } \\
\text { microplastics and they often focus only } \\
\text { on the environmental component, } \\
\text { which the problem they study relates to. }\end{array}$ & $\begin{array}{l}\text { One-sided view of where } \\
\text { the microplastics can be } \\
\text { found-fresh water and } \\
\text { sea water, and } \\
\text { water biota. }\end{array}$ \\
\hline $\begin{array}{l}\text { 4. What size of microplastics } \\
\text { would you expect? } \\
\text { Please indicate the size range. }\end{array}$ & $\begin{array}{l}\text { Exact sizes range: } 5 \text { millimetres to } \\
1-0 \text { micrometres (in accordance } \\
\text { with the research papers) or the } \\
\text { approximate size } \\
\text { range: micrometres. } \\
\text { We counted both answers as } \\
\text { correct, but we distinguished } \\
\text { between the exact size range and } \\
\text { approximate size range } \\
\text { during coding. }\end{array}$ & $\begin{array}{l}\text { Simple partial knowledge } \\
\text { Knowledge of an approximate size } \\
\text { range or just the upper size limit ( } 5 \mathrm{~mm} \text { ) } \\
\text { as provided mostly by media. } \\
\text { Derived partial knowledge } \\
\text { Based on the name "microplastics," } \\
\text { approximate size can be derived since } \\
\text { the size prefix (micro) is already } \\
\text { included in the term. } \\
\text { OR } \\
\text { Extended partial knowledge } \\
\text { Exact sizes range that needs to be } \\
\text { gained in other (more specialized) } \\
\text { sources since the analysed media } \\
\text { mostly do not report the exact size. } \\
\text { The scientific literature must be } \\
\text { mentioned as a source of information. }\end{array}$ & None \\
\hline
\end{tabular}


Table 1. Cont.

\begin{tabular}{|c|c|c|c|}
\hline Question & Correct Answer & $\begin{array}{l}\text { Partial Knowledge Difficulty } \\
\text { and Explanation }\end{array}$ & $\begin{array}{l}\text { Preconceptions or } \\
\text { Alternative Concept } \\
\text { Source (If Any) }\end{array}$ \\
\hline $\begin{array}{l}\text { 5. In accordance with your } \\
\text { knowledge of microplastics, } \\
\text { do you think that } \\
\text { microplastics might have } \\
\text { impacts on human health? } \\
\text { If yes, which? }\end{array}$ & $\begin{array}{l}\text { Answer Yes, and one of the strong } \\
\text { assumptions: } \\
\text { (a) inflammatory processes and } \\
\text { other immunological } \\
\text { responses_-gastrointestinal } \\
\text { system, respiratory system) } \\
\text { carcinogenicity or } \\
\text { mutagenicity (release of } \\
\text { additives from plastics; } \\
\text { binding of secondary } \\
\text { pollutants-hydrophobic } \\
\text { organic substances to the } \\
\text { surface), } \\
\text { (c) possible penetration into the } \\
\text { lymphatic system; } \\
\text { (d) cell death (necrosis } \\
\text { and apoptosis); } \\
\text { (e) oxidative stress. } \\
\text { A general description of the } \\
\text { problem without pointing to a } \\
\text { specific authority is sufficient. } \\
\text { OR } \\
\text { Answer No without any } \\
\text { explanation or with the } \\
\text { explanation that there has been no } \\
\text { scientific evidence yet. }\end{array}$ & $\begin{array}{l}\text { Simple partial knowledge } \\
\text { Answer No-since the media does not } \\
\text { provide clear information about the } \\
\text { impacts of microplastics on human } \\
\text { health impact. It does not provide } \\
\text { information or states that the effect on } \\
\text { human health has not yet been proven. } \\
\text { Extended partial knowledge } \\
\text { Answer Yes with any of the listed } \\
\text { correct explanations. This information } \\
\text { needs to be gained in other (more } \\
\text { specialized) sources since the most } \\
\text { analysed media do not clearly report } \\
\text { about the impacts on human health. } \\
\text { The scientific literature must be } \\
\text { mentioned as a source of information. } \\
\text { Complex partial knowledge } \\
\text { Drawing a parallel (analogy) between } \\
\text { some known and commonly } \\
\text { communicated effects of plastics and } \\
\text { microplastics on human health } \\
\text { (e.g., phthalates). }\end{array}$ & $\begin{array}{l}\text { Since there is no evidence } \\
\text { about the impacts of the } \\
\text { microplastics on human } \\
\text { health, we can't } \\
\text { determine the existence } \\
\text { of preconceptions or } \\
\text { alternative conceptions. } \\
\text { However, on the one } \\
\text { hand, the analysed } \\
\text { media reported that the } \\
\text { impacts on human health } \\
\text { has not been proven, } \\
\text { but on the other hand, } \\
\text { the information provided } \\
\text { by it makes the reader } \\
\text { feel that such impacts are } \\
\text { more than likely (use of } \\
\text { emotional discourse). } \\
\text { Thus, it will be } \\
\text { interesting to see to what } \\
\text { extent students are } \\
\text { affected by this } \\
\text { biased feeling. }\end{array}$ \\
\hline
\end{tabular}

All the questions prompted the students to choose the related knowledge source from a list of mass media, school, friends, no information, or other (with a blank space for specification). The test was completed individually by students during a lecture supervised by a teacher. This increased the return rate (to 90\%) and limited the influence of any external help (which was not allowed). We also collected information about the field of study of the students.

\subsection{Research Objectives and Assumptions}

The objective of this research was to discover what knowledge on the topic of microplastics students possess and what the sources of such knowledge are. We related the knowledge sources to the correctness of the answers; we were interested in the relations between the students' fields of study and the knowledge on the topic. The final survey item was aimed specifically at students who declared above-average interest in the topic by using other, in particular scientific, sources. We studied whether such students answered the survey questions more soundly and correctly than their peers. We used descriptive statistics (frequencies) for the analysis, similar to some of the methods used in Trends in International Mathematics and Science Study TIMSS [44] and Programme for International Students Assessment (PISA) [45] international surveys.

The tested relations allowed us to gain a better insight into the students' levels of environmental knowledge. The final sample size (384 students from several universities) allowed us to use inferential statistics (Pearson's Chi square test for contingency tables and the variance analysis—one way ANOVA) for all of the relation-based research objectives. The assumptions were as follows:

- There should be a relation between the knowledge source and survey answers. According to the European survey findings [36], we expected media to be the main source of knowledge- the students would therefore correctly answer the questions with spontaneously obtained answers (readily available/accessible) from the media. The frequency of correct answers on such questions by students without the information or with other sources of information would be lower.

- We assumed that there should be some relationship between the answers on the questions and the usage of other, especially scientific, sources. The assumption was that students using scientific 
publications would have a higher proportion of correct answers than students who have the information from the media, or no information on the topic.

- Finally, we assumed a relationship between the students' fields of study and their ability to answer correctly. The assumption was that students in science and technology would score better than those in humanities.

\subsection{Sampling, Data Acquisition, and Limitations}

The sample was gathered with the aim of helping the teachers understand how their students transform the information obtained in informal education into environmental knowledge. The university teachers assigning the tests to students were from five different regions, from universities of varied size with students in different fields. The sample consisted of 395 respondents, out of which 384 were ultimately included in the sample ( 11 respondents were excluded due to duplicated submission of the knowledge test/questionnaire form). They were students in technical (engineering) (43), scientific (240), and humanities (101) fields from seven out of twenty-six Czech public or state universities. The total population of university students in the Czech Republic is 290,000, thus our sample size may be considered adequate, and it allows us to draw some general conclusions at a confidence level of $95 \%$. However, the representativeness of the sample could not be verified, as the composition of the whole student population is unknown. Whenever any conclusions are to be drawn from this study, these limitations should be considered.

Although the information obtained is valid only for this group and serves as a feedback for teachers, we proved the reliability of the test. It was confirmed by collecting a new data sample (a test-retest method, $\mathrm{N}=120$ ) and correlating the results with our main study [46]. The Pearson's correlation coefficients for questions $1-5$ were $0.766,0.817,0.782,0.698$ and 0.657 , respectively, all significant at 0.01 level.

\subsection{Data Processing}

During data processing, duplications were first removed (see above), yielding 384 individual answer sets. Then, individual answers to the open-ended questions in the knowledge test were coded, based on their meaning and closeness to the scientific consensus (see Table 1). The coding was done analogically to the processing of the TIMSS survey based on explicit scoring guides containing correct answers to each question. The scoring guide's correctness was guaranteed by three experts in the field of microplastics. The answers were coded by three scorers independently for the whole examined sample. The degree of agreement between scores assigned by the three scorers is a reliability measure of the scoring process [44]. In this process, $95 \%$ reliability was achieved.

\section{Results and Discussion}

\subsection{Relation between the Knowledge Source and Survey Answers}

The information about the source and formation of microplastics appeared in $75 \%$ of the analysed media. All the media reported about at least one component of the environment where microplastics appears. However, "water" or "water and water biota" were mentioned as the only environmental components containing microplastics in $70 \%$ of them; $60 \%$ of the analysed media didn't provide any information about the size of microplastics; $27 \%$ reported an approximate size of microplastics, and $10 \%$ reported the exact size range; $40 \%$ of the analysed media didn't provide any information about the health impacts; about $40 \%$ of the analysed media reported that no impact had been proven yet; but about $40 \%$ of these media used emotional discourse raising concerns about possible impacts on human health. In contrast, $10 \%$ of these media noted that until studies proved such conclusions, concerns are not justified. Finally, $10 \%$ of the analysed media reported some impact on human health, including an explanation. 
The university students answered five questions about microplastics. More than $80 \%$ of all respondents determined the source of microplastics correctly but just $44 \%$ of all students were able to define both the source of microplastics and the mechanism of their origin; $28 \%$ of all students correctly identified all environmental components where humans may encounter microplastics; $30 \%$ of all students identified two out of four environmental components with the most frequent being water, and $21 \%$ of all students named only water as the environmental component potentially containing microplastics (another 14\% named water and water biota); $25 \%$ of all students assessed the approximate size range of microplastics (hundreds of micrometres) while only $4 \%$ out of all students knew the specific size range (from $5 \mathrm{~mm}$ to $1 \mu \mathrm{m}$ ); $88 \%$ of all students considered the impact of microplastics on human health as negative but just $22 \%$ of all students were able to identify any potential impact described in scientific literature. Only $7 \%$ of all students reported no impact of microplastics on human health and half of them stated that there was actually no evidence of such impact. The rest did not answer the question or did not express their opinion clearly. Only $0.5 \%$ of all students answered all five questions above correctly and thus demonstrated a complex knowledge of the theme.

\subsection{1. "Media" as a Source of Information}

The source of information varied from question to question; we can distinguish three main categories: "media," "no information," and "other sources" (community or school). Figure 1 shows that media was the main source of students' information for questions about the source, formation, and occurrence of microplastics in environmental components (nearly one half). In contrast, $50 \%$ of students reported no information about the size of microplastics and $52 \%$ no information about the impact on health. Media was the source of information for $27 \%$ of students concerning the size and for $31 \%$ of students concerning the health impact.

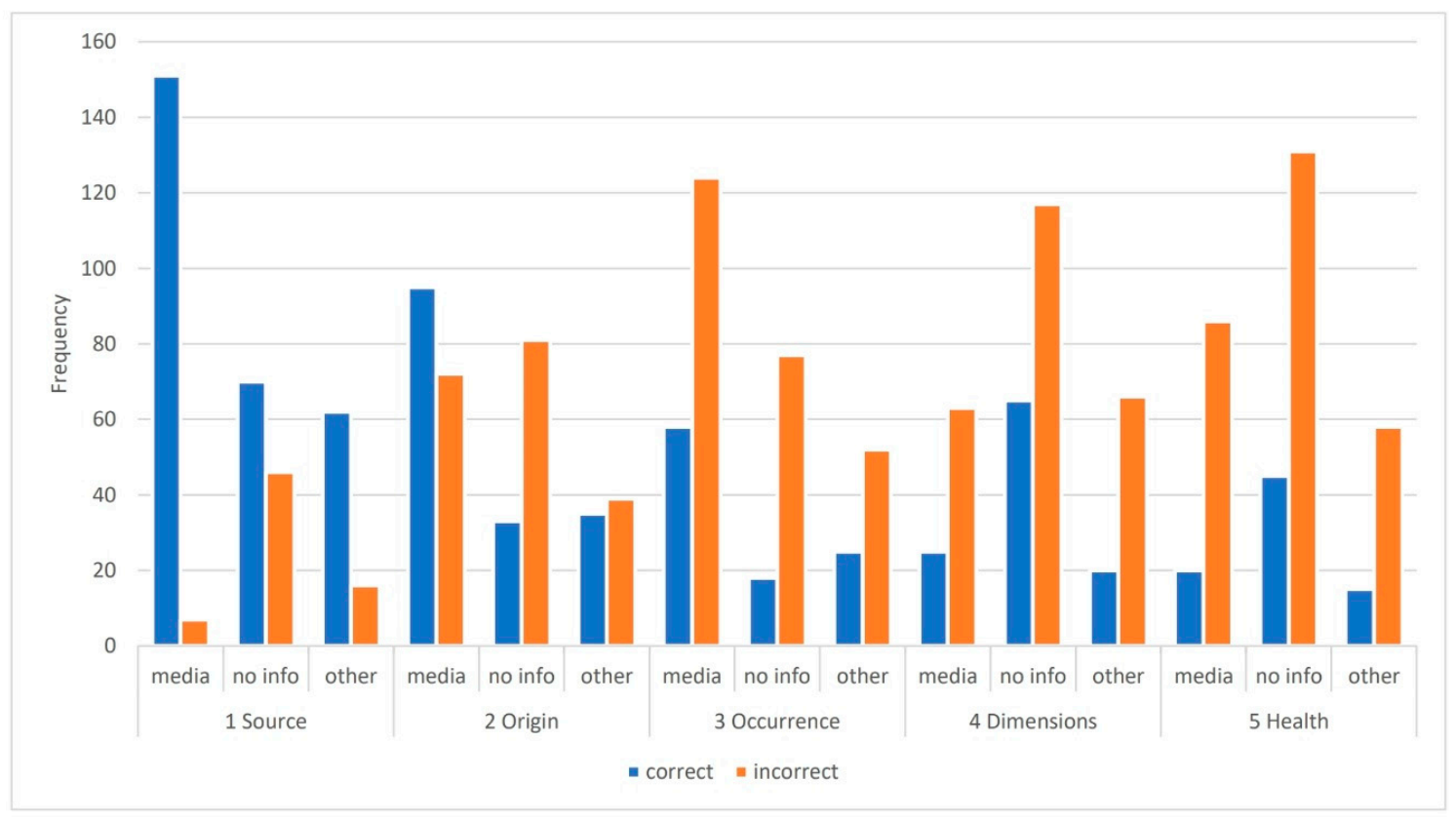

Figure 1. The source of students' information and correctness of the students' knowledge.

Questions with media as the main source of information had a high share of correct answers (93\%-microplastics source and 55\%-microplastics formation). The success rate was much lower for the questions on the microplastics size $(26 \%)$, microplastics occurrence in environmental components $(30 \%)$, and health impact $(20 \%)$. The percentage distribution of incorrect answers in the "microplastics occurrence in environmental components" was as follows: $21 \%$ identified water as the only environmental component; $31 \%$ identified water and one other environmental component. 
As we can see, the students' answers closely corresponded to what the majority of national mass media reports about microplastics. They transformed the facts basically correctly, regardless of the information complexity. Based on the statistical results, we may conclude that students having media as the main source of information acquired the simple partial knowledge concerning the microplastics source and formation well. Only a third of them, however, acquired the complex partial knowledge concerning environmental components, and two thirds of them expressed the preconception or alternative concept that microplastics occur only in water or in water and water biota. Hence, they adopted only the information communicated by media. Similarly, only one fifth of students were able to show the complex partial knowledge concerning the microplastics' impacts. They adopted the media's viewpoint-the concerns about the potential impacts—without having adequate justification. The low rate of correct answers (26\%) on the microplastics size was rather surprising and it was even worse than that of students with no information on the issue.

\subsection{2. "No Information" on the Subject Matter}

Similarly, frequent answers on the source of information as "media" was "no information" - $38 \%$ of all respondents (30\% to the question about the source and formation of microplastics, $26 \%$ to the question about environmental components, and $50 \%$ about the question on health impact). However, despite students' answers of "no information," they were able to answer correctly in many cases- $61 \%$ to the question about the source, $26 \%$ to the question about the formation of microplastics, and $18 \%$ to the question about environmental components. The question on microplastic's size had a higher success rate for students declaring "no information" than for those with information from media or other sources (35\%); a similar result was produced for the question about health impact (almost one quarter of the respondents). In addition, there was a higher share of respondents answering that there were no health impacts. Therefore, informal education - unintentional education in this case-apparently also influenced the students declaring no information on the subject issue. The simple partial knowledge concerning the source and formation of microplastics was lower (worse) than for students having information from the media and other sources, but their simple partial knowledge was remarkably higher (better) concerning the microplastics size-they applied a simple deduction from the term micro-plastics. Such a process is obvious from the questionnaires where in addition to "I have no information about the theme" respondents often noted in their answers "my estimation" or "I think so" - they were willing/capable to think the issue over even very simply. They also had slightly better knowledge about the health impacts ( $23 \%$ correct answers). The results may be influenced by a higher share of students stating that the health impacts are non-existent or proved-they expressed fewer worries about that. Interestingly, students without information on the subject matter had frequent answers on the environmental component containing "water" or "water and water biota," which we can again relate to the informal education as mentioned above.

\subsection{3. "Other Sources" of Information}

The least frequent category-information on microplastics from other sources-accounted for $21 \%$ of all answers and contained community (friends, family, classmates, neighbours, or others), research papers and school. A minimal share of all respondents $(0.3 \%)$ mentioned scientific papers and only $5.5 \%$ mentioned school as a source of information. In this category, the most common source was community (almost $60 \%$ ) and school $(40 \%)$. The microplastics source and formation correctly identified $85 \%$ respondents, and $47 \%$ respectively. The proportion of correct answers was thus higher than for students without information but slightly lower than for students with information from the media. Furthermore, more than one third of students correctly answered the question on environmental components and almost one fourth $(23 \%)$ on health impacts. This is a similar result as that achieved by students with information from the media. The question on the microplastics' size scored worst-only $23 \%$ correct answers. The results also imply that students in this category were the most often endowed with simple partial knowledge, but their share was lower than in the other two categories. With regard 
to the complex partial knowledge, the students with other sources of information had the same results as the students with information from the media.

The above descriptive statistics give a good clue about our first assumption about the existence of a relationship between the information source and the correctness of the answer. Due to data nature, we have used Pearson's Chi square test for the contingency tables (see results summary in Table 2) to determine the relationships between variables.

Table 2. Pearson's Chi square test for contingency tables between correct answer and source of information.

\begin{tabular}{|c|c|c|c|c|c|c|}
\hline & & $\begin{array}{c}\text { 1-Source } \\
\text { (Correct/Incorrect) }\end{array}$ & $\begin{array}{c}\text { 2-Formation } \\
\text { (Correct/Incorrect) }\end{array}$ & $\begin{array}{c}\text { 3-Occurrence } \\
\text { (Correct/Incorrect) }\end{array}$ & $\begin{array}{l}\text { 4-Dimensions } \\
\text { (Correct/Incorrect) }\end{array}$ & $\begin{array}{c}\text { 5-Health } \\
\text { (Correct/Incorrect) }\end{array}$ \\
\hline \multirow{3}{*}{$\begin{array}{c}\text { media } \\
\text { (yes/no) }\end{array}$} & Coefficient Phi & $0.281^{*}$ & $0.208^{*}$ & 0.052 & -0.060 & $0.133^{*}$ \\
\hline & $\chi^{2}(1)$ & 27.863 & 15.292 & 0.961 & 1.268 & 6.238 \\
\hline & $\begin{array}{l}\text { Asymp. sig. } \\
\text { (2-tailed) }\end{array}$ & 0.000 & 0.000 & 0.327 & 0.260 & 0.044 \\
\hline \multirow{3}{*}{$\begin{array}{l}\text { no information } \\
\text { (yes/no) }\end{array}$} & Coefficient $P h i$ & $-0.349^{*}$ & $-0.249^{*}$ & -0.138 * & 0.104 * & -0.148 * \\
\hline & $\chi^{2}(1)$ & 42.838 & 21.831 & 6.748 & 3.835 & 7.664 \\
\hline & $\begin{array}{l}\text { Asymp. sig. } \\
\text { (2-tailed) }\end{array}$ & 0.000 & 0.000 & 0.009 & 0.050 & 0.022 \\
\hline \multirow{3}{*}{$\begin{array}{l}\text { other } \\
\text { (yes/no) }\end{array}$} & Coefficient $P h i$ & 0.047 & 0.025 & 0.085 & -0.062 & 0.059 \\
\hline & $\chi^{2}(1)$ & 0.792 & 0.213 & 2.557 & 1.372 & 1.209 \\
\hline & $\begin{array}{l}\text { Asymp. sig. } \\
\text { (2-tailed) }\end{array}$ & 0.374 & 0.644 & 0.110 & 0.241 & 0.546 \\
\hline
\end{tabular}

* Correlation is significant at the 0.05 level (2-tailed).

There exist some relationships between the correctness of the answer to question 1 (microplastics' source) and the sources of information that are statistically significant. There is a weak positive relationship between the answers readily available/accessible in the media as obvious from $p h i=0.281$. For this question, there is also a moderately strong negative relationship ( $p h i=-0.349)$ for the category of "no information" showing worse students' knowledge. Analogically statistically significant relationships are found for particular categories of answers about microplastics' formations (question 2). A weak negative relationship is found between the answers for question 2 and "no information" as a source of information ( $p h i=-0.249$ ). Thus, these students performed worse than students who declared media as a source of information. For the category "media," a low positive relationship was found ( $p h i=0.208)$. A significant negative relationship, although slightly weaker, was found between the answers on environmental components (question 3) and sources of information from the category "no information" ( $p h i=-0.138$ ). This means that those students exhibited less knowledge than students citing media as an information source. A weak positive relationship was found between answers for question 4 (dimensions) and "no information" as a source of information ( $p h i=0.104$ ). These findings correspond with descriptive statistics-the probability of them answering correctly was greater than any other group of students. We propose that their estimation provided better results than knowledge recollection. An interesting finding is also the existence of a statistically significant relationship between answers regarding the impact of microplastics on human health and the category "media" as a source of information (with a weak positive relationship, phi $=0.133$ ) and the category "no information" with a weak negative relationship ( $p h i=-0.148)$. We can stress the overall significant negative weak or moderate relationships for the "no information" source, indicating that students who declared the no information source achieved significantly worse results except for question 4 (dimensions), where there is a weak positive relationship indicating that the students actually thought about it and correctly derived the right solution based on a prefix "micro."

\subsection{Relationship between the Answers to the Questions and the Usage of Other, Especially Scientific, Sources}

Our second assumption, that there should be a relationship between answers to the questions and the usage of others, especially scientific information sources, cannot be proven since the number of students using scientific sources was too low ( $0.3 \%$ of all responses). 


\subsection{Relationship between the Students' Field of Study and Their Ability to Answer Correctly}

The last test performed was ANOVA-to assess the differences in knowledge on the topic among students with different fields of study. There was no significant difference in the knowledge between the scientific and technical fields, whereas the knowledge of humanities students was significantly lower $\left(F(2,317)=7.264, p=0.001 ; M_{\text {humanities field }}=1.76 ; S D=1.08 ; M_{\text {technical fields }}=2.24 ; S D=1.1\right.$; $M_{\text {scientific fields }}=2.24 ; S D=1.100$ ), as shown by the Tukey's HSD (Honestly Significant Difference) test. However, the ANOVA effect size $\left(\eta^{2}=0.044\right)$ meant that even in the case of significance $(p=0.014)$, the effect of the field of study on the students' knowledge was small. We can thus presume a very slightly higher interest in the topic of microplastics in students of technical or scientific fields, whose knowledge was slightly better. Nonetheless, the humanities students also had some knowledge of the topic, so we can expect them to be interested in the topic as well.

\subsection{Teachers' Semistructured Interviews}

Each of the nine university teachers whose students participated in the testing underwent about an hour-long interview. We asked teachers questions closely related to our research questions, particularly about their assumptions (i) from where the (tested) students get the information about the new environmental topics (microplastics), (ii) how capable the students are of transforming the information from particular sources into knowledge of various complexity, (iii) if they would expect differences between the level of knowledge of students from different fields of study, and (iv) whether they would use the information for changes in their university courses. In response to the teachers' answers, the study results were presented to the teachers and further discussed in the context of the university curricula improvement. The analysis of the interviews showed that the results and conclusions of the study largely coincided with the observations of the teachers: students have a basic awareness of new, publicly discussed environmental topics but their knowledge does not reach far beyond a common community level. It was not surprising to find that if students had a sense that they already had the information from a particular source (e.g., media), they tried to recall the information rather than use some of the higher cognitive skills to help them to correctly answer the question (this concerned the approximate microplastics size and the occurrence in environmental components).

Most teachers stated that the orientation to acquire a large amount of knowledge at the expense of the development of higher cognitive skills still persists in education, which is repeatedly confirmed by the PISA studies (see e.g., [47]) and many Czech authors have pointed that out. Teachers of humanities expected significantly worse results for their students compared to science and engineering students and much better results for science students. There was absolute consensus among the university teachers about the need to adapt university courses to the goal to deepen (increase) students' environmental literacy (including critical thinking).

\section{Conclusions}

This study brings original findings complementing ongoing research on environmental literacy $-37 \%$ of students identified mass media as the main source of the knowledge; the other $35 \%$ of students declared no information about the topic; however, we can see they had some knowledge about the topic distilled from information provided by non-intentional informal education. This is proved by the frequency of adopting an alternative concept (or preconception) of microplastics' occurrence in water (and water biota). They are unintentionally biased by "overall awareness" about the topic discussed by the general public. One fifth of students declared other sources of information (community, school, etc.). The students generally had good knowledge of the microplastics' sources and the mechanisms of its formation. Their knowledge of the microplastics' size or their occurrence in various environmental components was relatively worse-only one third of all respondents answered correctly and only a handful of respondents gave examples of the assumed microplastics' health impacts. If we were to summarize, most students had some simple partial knowledge about the 
topic, which is at the level of commonly discussed information that students remember and then just reproduce. If they think they have information from a particular source, they try recalling it rather than using higher cognitive skills and deducing the correct answer (the microplastic's size, which students with information responded to less often correctly than students without information).

The fact that they don't think much about the topic proves that the media (as well as overall awareness) determines the knowledge basis, no matter how complex the knowledge basis is (sometimes complex and sometimes oversimplified in its representation). Some studies (see, e.g., [48]) show that the mass media can be a source of both knowledge and possible alternative concepts. In our case, one such partial alternative concept could be recognized, namely that "water" or "water and water biota" is the only environmental medium polluted by microplastics. However, it is not the fault of the mass media-such information is enough for "personal conduct knowledge," fits well in the pre-existing knowledge structure and allows for some basic action (e.g., to get a drinking water filter or to reduce the plastics use).

If (real) environmental literacy based on critical and problem-solving thinking is not developed enough, or the students do not apply it in everyday life, they may accept the information served by the mass media without thinking twice. We noticed two such situations within the five questions (complex partial knowledge). In the first, it did not cross the students' minds that microplastics behave in a similar manner as most substances and transfer among environmental components, and thus are present in soil, air, and biota as well as in water. Another (unused) opportunity was drawing a parallel with other anthropogenic pollutants in the environment and their potential impact on human health. From the answers, we presume that most students' level of environmental literacy stays at the point of personal conduct knowledge, not going any further. This might be a case of choosing the wrong information sources, incomprehension of such sources, or forgetting, possibly related to the information not being cemented in a more complex thought structure. Stevenson reports that in the 1970s and 1980s many environmental education curricula were offering only isolated pieces of information, concepts, and simple generalizations organized loosely within discrete bodies or fields of study [49]. He supports the inquiry-based educational process enabling students to be actively engaged in critical or complex thinking about real environmental problems. We assume that despite massive support for inquiry-based education in the Czech Republic, most environmental education (methods and themes) still confronts pupils mostly with isolated information and not enough critical thinking. This is in full concert with the 2015 PISA survey results-pupils there showed better knowledge of raw scientific facts than procedural and epistemic knowledge when dealing with scientific literacy [47]. Scientific literacy is a good example because of its close link with environmental literacy (see, e.g., [50]). Both procedural and epistemic knowledge are necessary to "identify questions that are amenable to scientific enquiry, to judge whether appropriate procedures have been used to ensure that the claims are justified, and to distinguish scientific issues from matters of values or economic considerations" [51]. Such capabilities are needed to assess complex environmental facts as well as to assess their links with the socioeconomic aspects of the sustainability concept.

Based on our findings and teachers' information in interviews we believe that ending the development of environmental literacy upon finishing higher secondary education is not an ideal situation. In full consent with [52], we assume that college-level education provides an opportunity for further development of critical thinking and strengthening higher cognitive skills of university students, using complex environmental topics strongly intertwined with the socioeconomic context of society. It also allows for the encouragement of transdisciplinary learning designs that initiate dialogue and discourse around real-world problems [53], regardless of the studies (humanities, technical education, or science). The oncoming generation-the future decision-makers and often policymakers-will have to face sustainability challenges. It should be the role of education to provide them with the capabilities of looking at such topics critically and to search for applicable solutions to any new puzzle. College-level education is the right, but not the only opportunity for such steps because it is based on the great intellectual potential of the students [54]. We consider and propose that environmental literacy and 
education should become a topic for intense discussion, and that further research, which explores the effective ways environmental literacy can be developed, not only in the Czech Republic but throughout the world, should be done.

The interest of young people would surely be great because the sustainable future of the planet is generally seen as a challenge for them, as can be seen from the popularity of current movements such as "Fridays for Future."

Author Contributions: Conceptualization, S.J., T.H., T.C.; methodology, S.J., P.T.; formal analysis, P.T., D.F., M.T.; writing — original draft preparation, S.J.; writing—review and editing, S.J., T.H.; visualization, P.T., M.T. All authors have read and agreed to the published version of the manuscript.

Funding: This research was funded by Charles University Research Centre Programme No. UNCE/HUM/024 and Progres Q16.

Conflicts of Interest: The authors declare no conflict of interest.

\section{References}

1. Yacoubian, H.A. Scientific literacy for democratic decision-making. Int. J. Sci. Educ. 2018, 40, 308-327. [CrossRef]

2. Kinslow, A.T.; Sadler, T.D.; Nguyen, H.T. Socio-scientific reasoning and environmental literacy in a field-based ecology class. Environ. Educ. Res. 2019, 25, 388-410. [CrossRef]

3. Diaz-Balteiro, L.; González-Pachón, J;; Romero, C. Sustainability as a Multi-Criteria Concept: New Developments and Applications. Sustainability 2020, 12, 7527. [CrossRef]

4. Barska, A.; Jedrzejczak-Gas, J.; Wyrwa, J.; Kononowicz, K. Multidimensional Assessment of the Social Development of EU Countries in the Context of Implementing the Concept of Sustainable Development. Sustainability 2020, 12, 7821. [CrossRef]

5. Roth, C.E. Environmental Literacy: Its Roots, Evolution, and Directions in the 1990s; Eric Clearinghouse for Science, Mathematics and Environmental Education: Columbus, OH, USA, 1992.

6. Coyle, K. Environmental Literacy in America: What Ten Years of NEETF/Roper Research and Related Studies Say about Environmental Literacy in the US; National Environmental Education \& Training Foundation: Washington, DC, USA, 2005.

7. Kaya, V.H.; Elster, D. A Critical Consideration of Environmental Literacy: Concepts, Contexts, and Competencies. Sustainability 2019, 11, 1581. [CrossRef]

8. Jeronen, E.; Jeronen, J.; Raustia, H. Environmental Education in Finland-A Case Study of Environmental Education in Nature Schools. Int. J. Environ. Sci. Educ. 2009, 4, 1-23.

9. Pan, C.T.; Hsu, S.J. Effects of a One-day Environmental Education Program on Sixth-Graders' Environmental Literacy at a Nature Center in Eastern Taiwan. Sustainability 2020, 12, 5043. [CrossRef]

10. Arcury, T.A.; Johnson, T.P.; Scollay, S.J. Ecological worldview and environmental knowledge: The "new environmental paradigm". J. Environ. Educ. 1986, 17, 35-40. [CrossRef]

11. Gambro, J.S.; Switzky, H.N. A national survey of high school students' environmental knowledge. J. Environ. Educ. 1996, 27, 28-33. [CrossRef]

12. Morrone, M.; Mancl, K.; Carr, K. Development of a metric to test group differences in ecological knowledge as one component of environmental literacy. J. Environ. Educ. 2001, 32, 33-42. [CrossRef]

13. McBeth, W.; Volk, T.L. The national environmental literacy project: A baseline study of middle grade students in the United States. J. Environ. Educ. 2009, 41, 55-67. [CrossRef]

14. Dounlap, R.Y.; Van Liere, K. The 'new Environmental Paradigm'. J. Environ. Educ. 1978, 9, 10-19. [CrossRef]

15. Pe'er, S.; Goldman, D.; Yavetz, B. Environmental literacy in teacher training: Attitudes, knowledge, and environmental behavior of beginning students. J. Environ. Educ. 2007, 39, 45-59. [CrossRef]

16. Wolfe, V.L. A survey of the environmental education of students in non-environmental majors at four-year institutions in the USA. Int. J. Sustain. High. Educ. 2001, 2, 301-315. [CrossRef]

17. Scholz, R.W.; Binder, C.R. Environmental Literacy in Science and Society: From Knowledge to Decisions; Cambridge University Press: Cambridge, UK, 2011.

18. McBride, B.B.; Brewer, C.A.; Berkowitz, A.R.; Borrie, W.T. Environmental literacy, ecological literacy, ecoliteracy: What do we mean and how did we get here? Ecosphere 2013, 4, 1-20. [CrossRef] 
19. Rosling, H.; Rosling, O.; Rönnlund, A.R. Factfulness: Ten Reasons We're Wrong about the World-And Why Things Are Better than You Think; Flatiron Books: New York, NY, USA, 2018.

20. Clement, J.; Brown, D.E.; Zietsman, A. Not all preconceptions are misconceptions: Finding 'anchoring conceptions' for grounding instruction on students' intuitions. Int. J. Sci. Educ. 1989, 11, 554-565. [CrossRef]

21. Nakhleh, M.B. Why some students don't learn chemistry: Chemical misconceptions. J. Chem. Educ. 1992, 69, 191. [CrossRef]

22. Taber, K.S. The Nature of the Chemical Concept: Re-Constructing Chemical Knowledge in Teaching and Learning; Royal Society of Chemistry: London, UK, 2019; Volume 3.

23. Taber, K.S. Modelling Learners and Learning in Science Education; Springer: Berlin/Heidelberg, Germany, 2013.

24. Hoidn, S. Student-Centered Learning Environments in Higher Education Classrooms; Palgrave Macmillan: New York, NY, USA, 2017; 453p.

25. Teaching Science for Understanding: A Human Constructivist View; Mintzes, J.J.; Wandersee, J.H.; Novak, J.D. (Eds.) Elsevier Academic Press: Burlington, MA, USA, 2005.

26. Ellen, P.S. Do we know what we need to know? Objective and subjective knowledge effects on pro-ecological behaviors. J. Bus. Res. 1994, 30, 43-52. [CrossRef]

27. Taxonomy of Educational Objectives, the Classification of Educational Goals-Handbook 1: Cognitive Domain; Bloom, B. (Ed.) McKay: New York, NY, USA, 1956.

28. Schultz, P.W. Inclusion with nature: The psychology of human-nature relations. In Psychology of Sustainable Development; Springer: Boston, MA, USA, 2002; pp. 61-78.

29. Carmi, N.; Arnon, S.; Orion, N. Transforming environmental knowledge into behavior: The mediating role of environmental emotions. J. Environ. Educ. 2015, 46, 183-201. [CrossRef]

30. Kaiser, F.G.; Fuhrer, U. Ecological behavior's dependency on different forms of knowledge. Appl. Psychol. 2003, 52, 598-613. [CrossRef]

31. Hungerford, H.R.; Volk, T.L. Changing learner behavior through environmental education. J. Environ. Educ. 1990, 21, 8-21. [CrossRef]

32. Jensen, B.B. Knowledge, action and pro-environmental behaviour. Environ. Educ. Res. 2010, 8, 325-334. [CrossRef]

33. Eshach, H. Bridging in-school and out-of-school learning: Formal, non-formal, and informal education. J. Sci. Educ. Technol. 2007, 16, 171-190. [CrossRef]

34. EC. Lifelong Learning: Citizens' Views; Office for Official Publications of the European Communities: Luxembourg, 2003. Available online: https://www.cedefop.europa.eu/files/4025_en.pdf (accessed on 28 October 2020).

35. EC. Attitudes of European Citizens towards the Environment. Special Eurobarometer 468. 2017. Available online: https:/op.europa.eu/en/publication-detail/-/publication/c138fd8e-d160-4218-bbd5-ecd2e0305d29/ language-en (accessed on 28 October 2020).

36. Jayawardena, P.R.; van Kraayenoord, C.E.; Carroll, A. Factors that influence senior secondary school students' science learning. Int. J. Educ. Res. 2020, 100, 101523. [CrossRef]

37. Cortese, A.D. The critical role of higher education in creating a sustainable future. Plan. High. Educ. 2003, $31,15-22$.

38. Tilbury, D. Environmental education for sustainability: A force for change in higher education. In Higher Education and the Challenge of Sustainability; Springer: Dordrecht, The Netherlands, 2004; pp. 97-112.

39. Conceição, P.; Ehrenfeld, J.; Heitor, M.; Vieira, P.S. Sustainable universities: Fostering learning beyond environmental management systems. Int. J. Technol. Policy Manag. 2006, 6, 413-440. [CrossRef]

40. Matsa, K.E.; Silver, L.; Shearer, E.; Walker, M. Western Europeans under 30 View News Media Less Positively, Rely More on Digital Platforms than Older Adults; Pew Research Center: Washington, DC, USA, 2018; Available online: https://www.journalism.org/2018/10/30/western-europeans-under-30-view-news-medialess-positively-rely-more-on-digital-platforms-than-older-adults/ (accessed on 28 October 2020).

41. Krathwohl, D.R.; Anderson, L.W. A Taxonomy for Learning, Teaching, and Assessing: A Revision of Bloom's Taxonomy of Educational Objectives; Longman: New York, NY, USA, 2009.

42. Keene, J.; Colvin, J.; Sissons, J. Mapping Student Information Literacy Activity against Bloom's Taxonomy of Cognitive Skills. J. Inf. Lit. 2010, 4, 6-20. [CrossRef]

43. Salkind, N. Encyclopedia of Research Design: Content Validity; SAGE Publications, Inc.: Thousand Oaks, CA, USA, 2013. 
44. Martin, M.O.; Mullis, I.V.S.; Hooper, M. Methods and Procedures in TIMSS 2015; TIMSS \& PIRLS International Study Center: Chestnut Hill, MA, USA; Lynch School of Education: Chestnut Hill, MA, USA; Boston College: Newton, MA, USA; International Association for the Evaluation of Educational Achievement (IEA): Amsterdam, The Netherlands, 2016.

45. OECD. PISA 2015 Technical Report; OECD: Paris, France, 2017.

46. Crocker, L.; Algina, J. Introduction to Classical and Modern Test Theory; Holt, Rinehart and Winston: Orlando, FL, USA, 1986.

47. Blažek, R.; Příhodová, S. Mezinárodni Šetření PISA; Národní zpráva. Přrírodovědná gramotnost; [PISA Survey. National Report. Scientific Literacy]; Prague Czech School Inspectorate: Prague, Czech Republic, 2016. (In Czech)

48. Boyes, E.; Stanisstreet, M. Global warming: What do high school students know 10 years on? World Resour. Rev. 2001, 13, 221-238.

49. Stevenson, R.B. Schooling and environmental education: Contradictions in purpose and practice. Environ. Educ. Res. 2007, 13, 139-153. [CrossRef]

50. Correia, P.R.M.; do Valle, B.X.; Dazzani, M.; Infante-Malachias, M.E. The importance of scientific literacy in fostering education for sustainability: Theoretical considerations and preliminary findings from a Brazilian experience. J. Clean. Prod. 2010, 18, 678-685. [CrossRef]

51. OECD. PISA for Development Assessment and Analytical Framework: Reading, Mathematics and Science; Preliminary Version; OECD: Paris, France, 2018.

52. Veisi, H.; Lacy, M.; Mafakheri, S.; Razaghi, F. Assessing environmental literacy of university students: A case study of Shahid Beheshti University in Iran. Appl. Environ. Educ. Commun. 2019, 18, 25-42. [CrossRef]

53. Probst, L.; Bardach, L.; Kamusingize, D.; Templer, N.; Ogwali, H.; Owamani, A.; Adugna, B.T. A transformative university learning experience contributes to sustainability attitudes, skills and agency. J. Clean. Prod. 2019, 232, 648-656. [CrossRef]

54. de Andrade, J.B.S.O.; Garcia, J.; de Andrade Lima, M.; Barbosa, S.B.; Heerdt, M.L.; Berchin, I.I. A proposal of a Balanced Scorecard for an environmental education program at universities. J. Clean. Prod. 2018, 172, 1674-1690. [CrossRef]

Publisher's Note: MDPI stays neutral with regard to jurisdictional claims in published maps and institutional affiliations.

(C) 2020 by the authors. Licensee MDPI, Basel, Switzerland. This article is an open access article distributed under the terms and conditions of the Creative Commons Attribution (CC BY) license (http://creativecommons.org/licenses/by/4.0/). 